\title{
Climate change and coupling of macronutrient cycles along the atmospheric, terrestrial, freshwater and estuarine continuum
}

Article

Accepted Version

Jarvie, H. P., Jickells, T. D., Skeffington, R. A. and Withers, P. J. A. (2012) Climate change and coupling of macronutrient cycles along the atmospheric, terrestrial, freshwater and estuarine continuum. Science of the Total Environment, 434. pp. 252-258. ISSN 0048-9697 doi:

https://doi.org/10.1016/j.scitotenv.2012.07.051 Available at https://centaur.reading.ac.uk/28962/

It is advisable to refer to the publisher's version if you intend to cite from the work. See Guidance on citing.

Published version at: http://www.sciencedirect.com/science/journal/00489697

To link to this article DOI: http://dx.doi.org/10.1016/j.scitotenv.2012.07.051

Publisher: Elsevier

All outputs in CentAUR are protected by Intellectual Property Rights law, including copyright law. Copyright and IPR is retained by the creators or other copyright holders. Terms and conditions for use of this material are defined in the End User Agreement. 


\section{www.reading.ac.uk/centaur}

\section{CentAUR}

Central Archive at the University of Reading

Reading's research outputs online 


\title{
Climate change and coupling of macronutrient cycles along the atmospheric, terrestrial, freshwater and estuarine continuum
}

\author{
${ }^{1}$ H. P. JARVIE, ${ }^{2}$ T. D. JICKELLS, ${ }^{3}$ R. A. SKEFFINGTON ${ }^{*},{ }^{4}$ P.J.A. WITHERS \\ ${ }^{1}$ Centre for Ecology \& Hydrology, Maclean Building, Crowmarsh Gifford, WALLINGFORD. \\ OX10 8BB. UK; \\ ${ }^{2}$ School of Environmental Sciences, University of East Anglia, NORWICH NR4 7TJ, UK; \\ ${ }^{3}$ Department of Geography and Environmental Science, University of Reading, PO Box 227, \\ READING RG6 6DW UK; \\ ${ }^{4}$ School of Environment, Natural Resources and Geography, Bangor University, BANGOR, \\ Gwynedd, LL57 2UW, UK. \\ *Corresponding author \\ Telephone: $\quad$ +44 1183787323 ; \\ Fax: $\quad$ +44 1189755865 ; \\ email: r.a.skeffington@ reading.ac.uk
}

\begin{abstract}
.
This paper provides an introduction to the Special Issue on "Climate Change and Coupling of Macronutrient Cycles along the Atmospheric, Terrestrial, Freshwater and Estuarine Continuum", dedicated to Colin Neal on his retirement. It is not intended to be a review of this vast subject, but an attempt to synthesize some of the major findings from the 22 contributions to the Special Issue in the context of what is already known. The major research challenges involved in understanding coupled macronutrient cycles in these environmental media are highlighted, and the difficulties of making credible predictions of the effects of climate change are discussed. Of particular concern is the possibility of interactions which will enhance greenhouse gas concentrations and provide positive feedback to global warming.
\end{abstract}

Keywords: Macronutrient cycles; climate change; carbon; nitrogen; phosphorus, food security, ecosystem services

\section{Introduction}

Biogeochemical cycles are fundamental to sustaining life on Earth, and support the productivity and diversity of both natural ecosystems and those managed for food production. Recently, concern has been growing that anthropogenic disruptions to these cycles, especially the macronutrient cycles of carbon $(\mathrm{C})$, nitrogen $(\mathrm{N})$ and phosphorus $(\mathrm{P})$, are damaging these support functions and associated ecosystem services (e.g. Finzi et al., 
2011a). Human activities have considerably increased flux rates in all three cycles - the $\mathrm{N}$ cycle through inputs from the Haber-Bosch process, and also from combustion of fossil fuels (Erisman et al., 2008); the P cycle from mining P deposits (Cordell et al., 2009); and the C cycle from fossil fuel combustion and increased biomass burning (IPCC, 2007). These increases have made our current industrial civilisation possible - the enhanced $\mathrm{N}$ and $\mathrm{P}$ inputs are needed to feed the current and future human population (Godfray et al., 2010), and the $\mathrm{C}$ from fossil fuels provides most of the energy needed to drive human activity. However, the side effects of these inputs are becoming increasingly troublesome: the increase of $\mathrm{CO}_{2}$ in the atmosphere is generating global warming (IPCC, 2007) and leakage of $\mathrm{N}$ and $\mathrm{P}$ from agricultural systems and human waste disposal systems is leading to a range of problems in all environmental media and ultimately posing a threat to human health. These problems include nutrient enrichment of soils; eutrophication of water bodies; reduced drinking water quality; loss of biodiversity; impaired air quality and general degradation of the biosphere support systems which can be characterised as ecosystem services (e.g. Chapin et al., 2010). With these problems in mind, it is clear that our understanding of macronutrient cycles, and particularly how they respond to human perturbations and how they are linked together, needs to be considerably enhanced in order to predict future problems and suggest remedies. To this end, various research programmes are under way, such as the UK Natural Environment Research Council (NERC) Macronutrient Cycles Programme, described by Whitehead and Crossman (this issue). This Special Issue of Science of the Total Environment entitled "Climate Change and Coupling of Macronutrient Cycles along the Atmospheric, Terrestrial, Freshwater and Estuarine Continuum" is a contribution to this research effort, and is dedicated to Colin Neal, who's 300 or so peer-reviewed publications span all these environmental media, and have made a huge contribution to the evidence base for understanding these issues.

Better understanding of macronutrient cycles better might help decrease the tension between several important global agendas. One is food security: given the projections of population growth and improving living standards, food production will need to increase in coming years, requiring even greater inputs of $\mathrm{N}$ and $\mathrm{P}$ fertilizers (Godfray et al., 2010). Meeting the population's food requirements whilst preserving our natural resources and capital and decreasing the impacts of nutrients on ecosystem services, biodiversity and human health is now a priority encompassed in the term 'sustainable intensification' (Royal Society, 2009; Foley et al., 2011). There are problems other than excessive supply of nutrients. The P cycle is a sedimentary cycle in which the major global pools of $\mathrm{P}$ are geological deposits with a residence time of c. $100 \mathrm{M} \mathrm{yr}$ (Schlesinger, 1997), turning them effectively into a nonrenewable resource on human timescales. The rapid mining of currently economic reserves of $\mathrm{P}$ has led to fears of a $\mathrm{P}$ crisis (short supplies, high prices) - $\mathrm{P}$ fertiliser prices have already increased beyond the means of farmers in some poorer nations (Elser and Bennett, 2011).

Understanding the influence of climate change and increasing $\mathrm{CO}_{2}$ concentrations on macronutrient cycles at all scales will be essential for accurate predictions of future global warming and avoidance of nasty surprises in the future. Research into macronutrient cycles represents a major challenge because it requires the integration of disparate science disciplines, and needs to capture processes and fluxes operating at many different spatial and temporal scales. Changes in ecosystems in response to environmental drivers or mitigation measures may not manifest themselves for decades, making them difficult to estimate. 
Nevertheless this research challenge is a necessary one and the papers in this issue seek to contribute to current understanding of macronutrient cycling rates and processes; the interactions between $\mathrm{C}, \mathrm{N}$ and $\mathrm{P}$ at different scales; and flux exchanges and transport processes at the air-land-freshwater-estuarine interfaces, and to assess the implications for productivity and eutrophication against a backdrop of climate change.

\section{Coupled Macronutrient Cycles}

It has long been realised (e.g. Bolin and Cook, 1983; Schlesinger, 1997) that biogeochemical cycles are not independent of each other, but are coupled (i) through common chemical \& biological reactions; (ii) with other elements e.g. Fe, Mo, Mn, S, via microbial metabolism (Burgin et al., 2011); and (iii) with ecological dynamics (Halliday et al, this issue; Neal et al, this issue, Palmer-Felgate et al., 2011). As an example, the enzyme nitrogenase which is responsible for $\mathrm{N}$ fixation requires both iron $(\mathrm{Fe})$ and molybdenum (Mo) as co-factors (see Finzi et al., 2011b). Where Fe and Mo are in short supply, their availability may limit the rate of $\mathrm{N}$ fixation, and where $\mathrm{N}$ availability controls primary productivity, which is a widespread situation in terrestrial, freshwater and estuarine environments, $\mathrm{C}$ assimilation and $\mathrm{P}$ uptake may be limited too. Thus the $\mathrm{C}, \mathrm{N}$ and $\mathrm{P}$ cycles are coupled to the less-studied Fe and Mo cycles.

Macronutrient cycles are coupled over time on various scales (Manzoni and Porporato, 2011). For instance, diurnal cycling of dissolved organic carbon is linked to the changing balance between net heterotrophic and net autotrophic activity in daylight and dark hours, and may affect $\mathrm{N}$ and $\mathrm{P}$ uptake and release. Event-based dynamics occur where biogeochemical cycles vary between baseflow and stormflow conditions, with control of cycling passing to the wider catchment during stormflow (Manzoni and Porporato, 2011; Halliday et al., this issue). There are seasonal patterns (Halliday et al. this issue, Neal et al, this issue), and even longer (decadal, century) timescales related to the retention and release of macronutrients from ancient stores. The demonstration (Trimmer, this issue) that caddis fly larvae in a British river obtain a significant amount of $\mathrm{C}$ from chemoautotrophic bacteria feeding on methane raises the possibility that ancient $\mathrm{C}$ derived from groundwater is supporting contemporary food webs and biogeochemical cycles.

Macronutrient cycles are coupled in space. The atmospheric, terrestrial, freshwater, estuarine and marine systems form a continuum which is connected physically by fluxes of water, gases and aerosols (Manzoni and Porporato, 2011). However, the hydrological flows are overwhelmingly one-way down the continuum, from atmosphere to ocean, and this has important implications. Dawson et al. (this issue) suggested that particulate organic carbon from upstream in the River Dee, Scotland, became more reactive and cycled faster as it passed downstream into areas influenced by arable agriculture which have higher nutrient concentrations.

Stoichiometry couples the macronutrient cycles and is an important control on productivity down the terrestrial-aquatic estuarine continuum (e.g. Schade et al., 2011). Sterner and Elser (2002) suggested that a study of the stoichiometric ratios of the major elements in organisms and their environment could elucidate many of the factors controlling ecological dynamics. Research attention has focussed on simple inorganic forms of the macronutrients since these 
are the forms which are normally considered to be taken up by plants and autotrophic microorganisms, although recent evidence suggests plants can take up peptide and aminoacid $\mathrm{N}$ at similar rates to inorganic $\mathrm{N}$ (Hill et al. 2012). However, it is clear from many of the papers in this issue that nutrient transport down the continuum involves many different forms of the macronutrients - notably those where the elements are incorporated into organic compounds (either particulate or dissolved) and particulate inorganic compounds as well as dissolved inorganic forms. Thus there are a plethora of more-or-less well-defined fractions such as dissolved organic $\mathrm{C}, \mathrm{N}$ and $\mathrm{P}$ (DOC, DON and DOP), particulate organic carbon (POC), a whole array of operationally-defined phosphorus fractions such as soluble or molybdate reactive phosphorus (SRP, MRP), dissolved inorganic or hydrolysable phosphorus (DIP, DHP), dissolved reactive phosphorus (DRP), particulate P (PP) and so on. P cycles between the various inorganic forms fairly readily, and there is active exchange between much of the particulate and dissolved inorganic P (e.g. Statham this issue), but the role of dissolved and particulate organic $\mathrm{P}$ is poorly understood compared to the other fractions. The same ignorance attaches to particulate and dissolved organic $\mathrm{N}$ - indeed many of the papers in this volume emphasise the scale of our ignorance of the organic forms of the nutrients. Dungait et al. (this issue) suggest that tracer technology offers the best potential for advances in our understanding of such $\mathrm{C}, \mathrm{N}$ and $\mathrm{P}$ transformations. The paper by Jarvie et al. (this issue) explores the relative role of colloidal $(<1 \mathrm{kDa})$ and truly dissolved substances in the transport of metals and macronutrients in rivers of various characteristics. Colloids dominated the filtered $(<0.45 \mu \mathrm{m})$ river water fraction in the upland rivers, whereas truly dissolved fractions were proportionally greater in the lowland rivers, probably linked to sewage effluent inputs. Another nutrient which cannot be neglected is silicon, important as a limiting factor for diatom growth in Spring (e.g. Neal et al., 2005).

Conventional wisdom was that there is a shift from $\mathrm{P}$ limitation in headwaters to $\mathrm{N}$ limitation downstream (e.g. Vitousek et al., 2010) - this view, however, is based on largely pristine environments. But in much of the world, in most ecosystems, macronutrient cycles are now coupled to anthropogenic factors and decoupled from pristine biogeochemical cycles (e.g. Moss, this issue) by such factors as downstream increases in both $\mathrm{P}$ and $\mathrm{N}$ from agricultural and wastewater sources, which disrupt these predicted stoichiometric transitions. One highly contested claim is that exclusive focus on $\mathrm{P}$ control in rivers has exacerbated $\mathrm{N}$-limited downstream eutrophication in estuaries and coastal waters (e.g. Paerl, 2009). In contrast, Elser et al. (2007) suggested that $\mathrm{N}$ and $\mathrm{P}$ limitation was surprisingly similar in the terrestrial, aquatic and marine environments. Worrall et al. (this issue) compared modelled land to water flux of $\mathrm{N}$ in the UK ( $2125 \mathrm{k}$ tonnes $\left.\mathrm{N} \mathrm{yr}^{-1}\right)$ with estimates of $\mathrm{N}$ fluxes to estuarine and ocean systems at the tidal limit (791 $\mathrm{k}$ tonnes $\left.\mathrm{N} \mathrm{yr}^{-1}\right)$, suggesting in-channel $\mathrm{N}$ losses which are equivalent to a loss of $55 \mathrm{~kg} \mathrm{~N} \mathrm{ha}^{-1} \mathrm{yr}^{-1}$ in the terrestrial catchment. This large figure implies that there is a lot of $\mathrm{N}$ metabolism occurring in river channels which would be susceptible to disruption by environmental change, with consequences which are unknown at present. The decoupling of pristine macronutrient cycling has important implications for a variety of issues such as reductions in nutrient use efficiency, nutrient retention capacity and the "self-cleansing" capacity of aquatic systems (see Chapin et al. 2011 and associated papers).

The papers in this Special Issue indicate that cycling and exchange between different 'pools' with different residence/turnover times along the continuum between atmosphere and ocean 
results in spatial discontinuities in $\mathrm{P}, \mathrm{N}$ and $\mathrm{C}$ retention and storage. Also clear is the importance of transition zones and 'hotspots' of biogeochemical N, P and C cycling at interfaces between environmental systems e.g. high rates of $\mathrm{S}$ and $\mathrm{N}$ cycling under trees due to their ability to capture dry deposition from the atmosphere (Skeffington and Hill, this issue); OC fluxes and transformations in lability of $\mathrm{C}$ fractions as they move from terrestrial to freshwater environments (Dawson et al., this issue). These may have implications for downstream ecology (Bowes et al., this issue). The management of nutrient concentrations along the atmosphere-ocean continuum needs to be considered in a much more integrated way, as suggested by Conley at al. (2009) and explored further in this issue for agricultural environments (Dungait et al., this issue), aquatic environments (Moss, this issue) and estuarine environments (Statham, this issue).

\section{Atmospheric Interfaces}

The macronutrient cycles are coupled even when considering fluxes into and out of the atmosphere. Two papers in this volume (Àvila and Rodà, this issue; Skeffington and Hill, this issue) explore some of the consequences of the marked reductions in the deposition of acidifying substances to contrasting forested catchments in different parts of Europe. These reductions are due to legislation and international agreements which restrict the emissions of reactive $\mathrm{N}$ and $\mathrm{S}$ compounds (see Skeffington and Hill, this issue). But $\mathrm{S}$ and $\mathrm{N}$ deposition are not independent. $\mathrm{SO}_{2}$ and $\mathrm{NH}_{3}$ co-deposit (e.g. Mcleod et al., 1991) and as $\mathrm{S}$ emissions have declined much more than $\mathrm{NH}_{3}$ emissions in Europe, this implies that the amount of $\mathrm{S}$ deposition for a given $\mathrm{SO}_{2}$ concentration has generally increased. The formation of ammonium nitrate and ammonium sulphate aerosols is also affected by the relative ratios of atmospheric $\mathrm{S}$ and $\mathrm{N}$ compounds, and the result is that geographical patterns of $\mathrm{S}$ and $\mathrm{N}$ deposition have changed considerably and non-linearly (compared to emission changes) over the last 20 years (e.g. Fowler et al., 2007). This coupling of the $\mathrm{S}$ and $\mathrm{N}$ cycles in the atmosphere has led to very large changes in deposition in places, with the Tillingbourne Catchment in S England demonstrating an 89\% reduction in dry S deposition and a $98 \%$ reduction in acid $\left(\mathrm{H}^{+}\right)$deposition as measured in the throughfall water under trees (Skeffington and Hill, this issue). This in turn has implications for catchment soils and waters, and $\mathrm{N}$ export down rivers to the estuarine and marine environments. In the Mediterranean catchment studied by Àvila and Rodà (this issue) declining sulphate deposition over 25 years seems to have increased alkalinity in the river draining the catchment, aided by increased weathering due to higher temperatures as the local climate warms. Both catchments are retaining most of the atmospheric $\mathrm{N}$ which falls on them: but in both nitrate concentrations in the drainage streams are slowly increasing.

The $\mathrm{C}$ cycle is also coupled to the other biogeochemical cycles at various points. Methane production from peat appears to be inhibited by sulphate and nitrate deposition (e.g. Watson and Nedwell, 1998) - as S and $\mathrm{N}$ deposition decreases, methane emission from wetlands may therefore increase. Methane emission from freshwaters is influenced by interactions between the N, P, C, S, Fe, and Mn cycles - in lakes these relationships are well-established as described by Moss (this issue). Reduced S deposition appears to be implicated in the increased export of dissolved organic carbon in rivers in Europe and N. America (Evans et al., 2005). 
Phosphorus fluxes to and from the atmosphere have been much less studied than the other macronutrients (e.g. Mahowald et al., 2008) and there are still large gaps in our knowledge. The importance of atmospheric interactions (if any) between $\mathrm{P}$ and the other macronutrients is one of these. For nitrogen-poor habitats, $\mathrm{N}$ deposition may be the dominant source of $\mathrm{N}$ for plant growth - e.g. for extensively-managed habitats in Britain, atmospheric $\mathrm{N}$ deposition correlates well with mineralisable $\mathrm{N}$, showing that it is the main source of $\mathrm{N}$ in these systems (Rowe et al., this issue). $\mathrm{N}$ deposition may increase to the extent that vegetation in these areas becomes P-limited (e.g. Pilkington et al. 2005). These examples highlight the degree of interconnectedness of the biogeochemical cycles, and show the difficulty of making credible predictions of the future course of events, even just considering the interface between the atmosphere and the other environmental media.

\section{Land-Freshwater Interface}

In areas away from intensive agricultural activity, atmospheric deposition of nitrogen is a major source of $\mathrm{N}$ to terrestrial ecosystems and a key agent causing vegetation change, but in intensively managed agricultural systems such as are now widespread throughout the world, this atmospheric supply is further enhanced by release of nutrients from these agricultural systems. Intensification of agriculture in recent decades encouraged by subsidies has led to a widespread dependence on $\mathrm{N}$ and $\mathrm{P}$ fertilizers, resulting in a decoupling of $\mathrm{N}$ and $\mathrm{P}$ cycling rates from those of $\mathrm{C}$. Food processing, the concentration of the human population in urban areas and a high dependence on meat-based diets has accelerated this decoupling, especially for P (Filippelli, 2008; Cordell et al., 2009). The increased and widespread use of fertilizers and the lack of adequate recovery and recycling of nutrients have reduced nutrient use efficiencies in the food chain to a very low level. A case study for China by Ma et al., (this issue) reveals a complex and regionally varied picture, but a clear trend to lower nutrient use efficiency for both $\mathrm{N}$ and $\mathrm{P}$ occurred between 1980 and 2005. As a result, there are large increases in leaching of both $\mathrm{N}$ and $\mathrm{P}$ and increased emissions of $\mathrm{NH}_{3}$ and $\mathrm{N}_{2} \mathrm{O}$. In many parts of the world, crop production systems have become geographically separated from animal production systems, leading to large regional variation in nutrient surpluses, wastage and losses to air and water. Dungait et al. (this issue) argue that improvements in nutrient use efficiency can only be achieved through a greater understanding of the interactions between the different phases of $\mathrm{C}, \mathrm{N}$ and $\mathrm{P}$ (gaseous, solution and particulate).

Increased availability of $\mathrm{N}$ and $\mathrm{P}$ together enhance primary production beyond that produced by either element alone (Vitousek et al., 2010; Harpole et al., 2011), whether it be a positive effect on land (crop production) or a negative effect in freshwaters (algal growth). In turn, $\mathrm{N}$ and $\mathrm{P}$ supply stimulates microbial activity and $\mathrm{C}$ turnover with variation in how quickly different forms of $\mathrm{C}$ can be utilized, for example in the aquatic environment (Dawson et al., this issue). Soils and long-lived biomass represent a major planetary carbon store and the stability of this stored carbon influences atmospheric greenhouse gas concentrations and climate. The potential for $\mathrm{C}$ assimilation on land depends on nutrient supply, water availability and light whilst those in freshwaters are governed more by residence time and light. Bowes et al. (this issue) found that light was the most important factor controlling algal growth in the River Thames. The riparian and hyporheic zones that join the terrestrial to the aquatic environment are key areas of nutrient interchange and flux transformation (Trimmer et al., this issue). Isaac et al. (this issue) report transfer of $\mathrm{N}$ between roots of Acacia and durum wheat when intercropped at optimum $\mathrm{P}$ fertility, but understanding of rhizosphere 
interactions of $\mathrm{C}, \mathrm{N}$ and $\mathrm{P}$ as a basis for the development of nutrient-conserving systems is poor. Progress is being made in mathematical modelling of soil-root-crop nutrient and water interactions (Roose and Schnepf, 2008 , but this needs to be coupled with the development of techniques to manage the supply of $\mathrm{N}$ and $\mathrm{P}$ at a rate that does not lead to $\mathrm{N}$ accumulation at times of the year vulnerable to leaching.

In extensively managed agricultural systems, the processes responsible for $\mathrm{N}$ and $\mathrm{P}$ transformations in soils and water are biologically mediated. In anthropogenically disturbed systems, a heavy reliance on chemical inputs inhibits biological controls over nutrient supply with increased dominance of inorganic and more mobile forms of $\mathrm{N}$ and $\mathrm{P}$. Consequently, nutrient cycling rates and fluxes to the oceans via the river network have greatly increased over time predominantly via physical (e.g. erosion) and chemical (e.g. leaching) processes (Vitousek et al., 2009; Quinton et al., 2010) rather than biological processes. This shift has further exaggerated the fundamental differences between the macronutrients in terms of reactivity, loss processes and fluxes across the land-water interface with implications for $\mathrm{C}$ turnover and transfer. At the field scale, $\mathrm{N}$ fluxes across the land-water interface are largely driven by the accumulation of mineral $\mathrm{N}$ in the soil delivering nitrate to groundwater or to land drains via leaching (Rowe et al., this issue; Stenberg et al., this issue). Field scale P fluxes are also driven by soil $\mathrm{P}$ accumulation but in contrast to $\mathrm{N}, \mathrm{P}$ is highly reactive and bound to soil particles and delivery largely occurs in soil wash from specific areas, especially those susceptible to erosion (Stenberg et al., this issue). Eroding particles have enriched $\mathrm{P}$ and $\mathrm{C}$ contents relative to the soil from which they were derived. Smaller amounts of other forms of $\mathrm{N}$ and $\mathrm{P}$ are delivered in surface runoff or via drainflow following poorly timed field applications of manure or less importantly via grazing (Newell-Price et al., 2011; Worrall et al., this issue).

At larger scales, landscape, hydrology and land management (soil, crop and livestock) all exert interacting controls over $\mathrm{C}, \mathrm{N}$ and $\mathrm{P}$ fluxes and the ratios of these macronutrients delivered to the freshwater environment are often very different stoichiometrically to the requirements for primary production leading to temporally varying nutrient limitation and to storage and remobilization in different parts of the landscape. As shown by Stenberg et al. (this issue) more integrated or organic systems that rely less on inputs of chemical $\mathrm{N}$ and $\mathrm{P}$ fertilizers are not necessarily less leaky if soil and crop management are not optimised to capture the $\mathrm{N}$ and $\mathrm{P}$ released from biologically-mediated processes operating in the soil. Land management drivers associated with $\mathrm{N}$ and $\mathrm{P}$ loss (e.g. proportion of improved pasture) are also relevant for pathogen transport (Tetzlaff et al., this issue). That subtle alterations to farm management practice can have a considerable effect on nutrients and faecal indicator organisms is illustrated by the paper by $\mathrm{F}$ and Watson (this issue). Evidence is also growing that aquatic nutrient enrichment strongly influences the fate and effects of other non-nutrient contaminants, including pathogens (Smith and Schindler, 2009). Managing macronutrients for optimum crop production has largely occurred at the field scale where farm management decisions are historically made. As environmental concerns over air and water pollution have emerged, the new unit of management for macronutrients is now the catchment. Catchments differ enormously in size from headwaters of less than $1 \mathrm{~km}^{2}$ to major rivers with a million times that or more. This increase in scale produces additional complexities and research challenges and will require different monitoring and management strategies from the field scale. At the catchment scale, headwater sources and pathways of $\mathrm{N}$ and $\mathrm{P}$ transfer become 
mixed with downstream sources, making it much more difficult to apportion sources, link sources to impacts and prioritise mitigation strategies.

A variety of sources contribute fluxes with differing concentrations at different times of the year both during and between storm events requiring a sophisticated level of continuous monitoring to unravel (Jordan et al.; Neal et al., Halliday et al., all this issue). The dedicatee of this Special Issue, Colin Neal, has helped to pioneer an approach in which sophisticated mathematical analysis is used to extract patterns from stream chemistry data which allow catchment processes to be inferred - such as the demonstration that chloride concentrations in the stream draining the Plynlimon Catchment exhibit fractal 1/f scaling, which implies that its travel times follow an approximate power-law distribution and hence retain a long chemical memory of past inputs (Kirchner et al., 2000). This sort of insight is now being supported by high-frequency chemistry data collection (e.g. Jordan et al.; Neal et al.(this issue; Wade et al., 2012) and novel ways of analysing these data (Halliday et al., this issue).

Transformations between different forms of $\mathrm{N}$ and $\mathrm{P}$ occur during downstream transport, depending on residence times, with fundamental differences between lakes and rivers (Edwards and Withers, 2008). When discharge is flashier, hydrology is a more important driver for $\mathrm{N}$ and $\mathrm{P}$ concentrations than source pressure or land management (Jordan et al., this issue), although land management itself can impact on flow volumes and pathways. Jordan et al. (this issue) argue a case for including a hydrology metric within the current regulatory framework which relies heavily on source pressure reduction to achieve water quality goals. Uncertainties in flux estimates across the land -water interface increase at the catchment scale because of inadequate frequency of monitoring and our lack of understanding of the role of in-stream processing. Modelling studies by Worrall et al.(this issue) suggest $60 \%$ retention of $\mathrm{N}$ within river channels, and values of up to $60 \%$ have also been reported for $\mathrm{P}$ (Withers and Jarvie, 2008) and an understanding of these processes is therefore critical to predict and manage impacts downstream. This highlights that freshwaters are not simply a passive transport system, but act as 'reactive conduits' between the land and estuarine/marine environment. As another example, Trimmer at al. (this issue) discuss the extensive metabolism of $\mathrm{N}$ and $\mathrm{C}$ performed by rivers which make them important and underestimated players in the global $\mathrm{C}$ and $\mathrm{N}$ cycles. Trimmer et al., (this issue) and Moss (this issue) also discuss the implications for nutrient availability and climate change of the storage and legacy of macronutrients in catchments.

\section{Freshwater - Estuarine Interface}

The increasing fluxes of nutrients through the fluvial system (from both rivers and groundwater) inevitably have an important influence on the biogeochemistry of the coastal seas (Statham this issue). The societal value of these coastal ecosystems has been illustrated within an environmental economics analysis of global ecosystems (Costanza et al., 1998). The new NERC macronutrients programme (Whitehead and Crossman, this issue) finishes in the estuarine system as do the contributions to this volume, but it is important to recognise that the impact of increasing fluvial nutrient fluxes may be deleterious to the coastal seas (e.g. Diaz and Rosenberg 2008) although the impacts depend critically on the physical environment within the shelf sea (e.g. Jickells, 1998, von Bodungen and Turner 1999). A 
new NERC research programme on Shelf Sea Biogeochemistry is in development which should contribute valuable new information in this area.

The cycling of nutrients within estuarine systems and the impact on ecosystems is a difficult subject, particularly because of the complex flows within estuaries associated with tidal flows (Statham this issue). One important result of this is that estuarine systems may be very turbid and hence light limitation can limit primary productivity. Even where light levels do allow algal blooms to develop, their dynamics are profoundly influenced by the hydrodynamics of the system on time scales from minutes through diurnal cycles to spring/neap tidal cycles, in addition to annual cycles driven by light and longer term changes in river flow. The complexity of these effects is well illustrated by Tappin et al. (this issue). These complexities make developing simple relations between inputs and impacts very difficult and also make it necessary to consider management at the level of individual systems, rather than using the same approach everywhere. Tappin et al. and Statham (both this issue) also illustrate that in estuaries, as elsewhere throughout the fluvial system, the nutrient cycles are profoundly interlinked. This applies not only to nitrogen and phosphorus, but also to silicon with important implications for phytoplankton bloom species composition associated with changing nutrient ratios of changing nutrient ratios. Public perception of environmental problems within a catchment will be influenced by the site of blooms and their products, rather than from a knowledge of nutrient flows per se, and hence bloom incidence can be an important driver of policy responses (von Bodungen and Turner 1999).

Throughout catchments and particularly within estuarine systems, human activity has modified flows, often straightening river systems as part of flood management (e.g. Carpenter et al., 2011). In estuaries, this is scaled up further with removal of intertidal areas to reclamation for urban development. The importance of estuaries as trade routes and human societal development has made them a focus for population growth and created pressure on land. This is leading to large scale of loss of intertidal and some subtidal habitats. It is estimated that $30-50 \%$ of mangroves, salt marshes and sea grass beds have been lost, and this process continues (Copertino, 2011). These habitats are important ecosystems in their own right and also play a key role in nutrient cycling. Adams et al. (this issue) discuss the role of salt marshes in nutrient and carbon cycling, considering in particular the possibility of managed realignment to recreate these intertidal environments. Climate change and associated sea level rise is requiring changing coastal management practices and these have the possibility of contributing to mitigation of climate change, via carbon storage, and nutrient retention. This kind of approach has been shown to bring economic as well as environmental benefits (e.g. Andrews et al., 2006). The management of wetlands illustrates some of the complexity of the linkages between nutrient cycles. Primary production incorporates carbon, nitrogen and phosphorus into organic matter which can subsequently be buried in sediments. The breakdown of this organic matter will release all of these components. However, burial can also consume oxygen and in oxygen deficient environments, nitrate will be used as an alternative electron acceptor and potentially denitrified to gaseous products and lost from the system, while phosphorus can be mobilised under reducing conditions and Fe(III) reduction (Statham, Trimmer et al., both this issue) Therefore, as Adams et al.(this issue) show in evaluating the role of such wetlands as $\mathrm{CO}_{2}$ sinks, it is necessary to consider the emissions of the greenhouse gases $\mathrm{N}_{2} \mathrm{O}$ and $\mathrm{CH}_{4}$ from these systems which offset some of the benefits of carbon storage. This analysis illustrates 
one way in which marine systems differ somewhat from freshwater systems, since in marine systems the abundance of sulphate and its use as a terminal electron acceptor reduces the emissions of methane (Andrews et al., 2012).

\section{Climate Change Interfaces}

As the climate changes, the fluxes of the macronutrients and the biogeochemical responses to those fluxes will all change, as pointed out by several contributors to this Special Issue (e.g. Moss, Statham, Trimmer et al., all this issue). Predicting what will happen is, however, fraught with uncertainty as the experimental evidence supporting many of the predictions is rather sparse, as Moss (this issue) discusses for lakes. The impacts of these changes on ecosystem services and biodiversity is also unclear, but probably detrimental. A recent analysis of the impacts of 11 climate change scenarios on river flows in Britain in 2050 suggests decreases in Spring, Summer and Autumn flows of up to 80\%, although the predictions for Spring and Autumn were less certain (Prudhomme et al., 2012). Impacts of climate change on water resources may affect nutrient cycling as much as more direct effects on primary production, microbial activity and abiotic processes. It is clear, however, that interactions between $\mathrm{C}, \mathrm{N}$ and $\mathrm{P}$ cycles along the atmospheric, freshwater, estuarine and marine continuum are integral to the partitioning of $\mathrm{C}$ between different biosphere stores (Aufdenkampe et al., 2011; Finzi et al., 2011b). Though the oceans have long been known to play a play a key role in regulating $\mathrm{C}$ and providing climate feedbacks, feedbacks from the coastal and estuarine ecosystems are attracting increasing attention (e.g. Matear et al., 2010; Statham, this issue), and the aquatic and terrestrial environments have a large potential to slow or amplify global warming (e.g. Finzi et al., 2011b; Trimmer et al., this issue).

Of particular concern are feedbacks from the macronutrient cycles which might increase the flux of $\mathrm{C}$ to the atmosphere and thus amplify the effects of warming. Moss (this issue) reviews some of the possibilities for lakes and the strength of the evidence for them. Mesocosm experiments with warming treatments have shown increases in community respiration compared to gross photosynthesis, implying that increased net heterotrophic activity, resulting from climatic warming, has the potential to mobilise 'legacy' macronutrient stores, especially $\mathrm{C}$ stores in wetlands and shallow lakes in boreal and tundra regions, resulting in $\mathrm{CO}_{2}$ and $\mathrm{N}_{2} \mathrm{O}$ release generating a potential "runaway greenhouse" feedback scenario (Moss, this issue). Another possibility identified by Moss (this issue) is that earlier onset and longer duration of net primary productivity in lakes will lead to an increase in the magnitude and duration of hypolimnion anoxia, resulting in higher rates of $\mathrm{CH}_{4}$ release. Increased productivity, leading to more labile organic $\mathrm{C}$ forms, may be more readily metabolised to produce respiratory $\mathrm{CO}_{2}$. This has the potential to increase $\mathrm{C}$ loss to the atmosphere by degassing of $\mathrm{CO}_{2}$ from freshwaters, rather than storage of organic $\mathrm{C}$ in sediments (Dawson et al, this volume). Much of the $\mathrm{CO}_{2}$ originally produced in the terrestrial environment is leached into rivers and degasses from there on the way to estuaries and the ocean (Aufdenkampe et al., 2011).

Climatic warming and increased $\mathrm{C}$ mobilisation may increase denitrification in aquatic systems, but this may be offset by increased $\mathrm{N}$ fixation (Moss, this issue). Increased $\mathrm{N}$ fixation and $\mathrm{N}$ deposition may shift nutrient limitation in terrestrial (and some aquatic) systems from $\mathrm{N}$ limitation to $\mathrm{P}$ limitation, which may thus become a key control on the 
biosphere's capacity to take up $\mathrm{CO}_{2}$. The response of environments down the terrestrialestuarine continuum may change in different ways. In the oceans, ecosystem respiration (ER) is tightly coupled to gross primary productivity (GPP); in freshwaters, in contrast, allochthonous organic subsidies from land-based sources fuel metabolism far beyond that which could be sustained by autochthonous production alone. As ER responds much more rapidly to warming than GPP, this suggests that freshwaters have the potential to accelerate as net sources of $\mathrm{CO}_{2}$ to the atmosphere under a warming climate (Trimmer et al., this volume).

Changes in climate other than warming are also likely to affect macronutrient cycling. Jordan et al. (this issue) show that the wetter winters and drier summers predicted by current climate change modelling for the UK would probably increase stream $\mathrm{P}$ concentrations during both storms and baseflow, and would be particularly magnified in those catchments with flashy runoff. Tappin et al. (this issue) predict that decreased freshwater flushing in the Taw estuary in Cornwall is likely to lead to an increased risk of algal blooms both in the estuary and the adjacent ocean. The impact of nutrient loads on estuaries and coasts is very dependent on the physical setting. In estuaries the arrival of tidal energy to mix and exchange water and resuspend sediment makes this physical control larger, more important and more dynamic, and may mitigate the effects of decreased freshwater runoff to some extent (Tappin et al. and Statham, both this issue). Key drivers in climatic regions other than the UK are likely to have different responses, but change and its consequences is likely to occur everywhere.

A final issue related to climate change is mitigation. Adams et al. (this issue) investigated the effects on net greenhouse gas fluxes and nutrient loads of both restored and natural estuarine wetlands. The restored wetlands were capable of sequestering significant amounts of $\mathrm{C}$ and $\mathrm{N}$, more (at least in the short term) than the natural wetlands.

Evaluating the effects of possible climate change and mitigation possibilities down the atmosphere-estuarine continuum is a huge research challenge. Improved process understanding is clearly required, supported by better data. Development of high frequency in situ nutrient analysis systems will provide data to improve predictive models in both estuarine (Statham, this issue) and freshwater systems (Jordan, this issue; Wade et al. 2012).

\section{Conclusion}

The papers in this issue both demonstrate that a holistic, integrated approach is needed to effectively understand, predict and manage the impact of macronutrients on the atmosphericestuarine continuum, and illustrate the major challenges of doing so. The career of Colin Neal has provided the research community with both innovative concepts to aid the understanding of nutrient cycling in all these environmental media, and a large volume of high quality data to allow the testing of hypotheses relating to vital environmental issues. We dedicate this volume to Colin on his retirement. 


\section{References}

Adams CA, Andrews JE, Jickells T. Nitrous oxide and methane fluxes vs carbon, nitrogen and phosphorus burial in new intertidal and saltmarsh sediments, Sci Tot Environ 2011, this issue.

Andrews JE, Burgess D, Cave RR, Coomes EG, Jickells TD, Parkes DJ, Turner, RK. Biogeochemical value of managed realignment, Humber Estuary UK. Sci Tot Environ 2006;371:19-30.

Andrews JE, Jickells TD, Parkes DJ Adams, C. Biolimiting elements (C,N,P, Si) including isotopic composition and fractionation. In: Treatise on Coastal and Estuarine Science Vol 4 Dordrecht: Elsevier; in press, 2012.

Àvila A Rodà, F. Changes in atmospheric deposition and streamwater chemistry over 25 years in undisturbed catchments in a Mediterranean mountain environment, Sci Tot Environ 2011, this issue.

Aufdenkampe AK, Mayorga E, Raymond PA, Melack JM, Doney SC, Alin SR, et al. Riverine coupling of biogeochemical cycles between land, oceans, and atmosphere. Front Ecol Environ 2011;9:53-60.

Bolin B, Cook, R B. The major biogeochemical cycles and their interactions. Chichester: John Wiley; 1983.

Bowes M J, Ings NL, McCall SJ, Warwick A, Barrett C, Wickham HD, et al. Nutrient and light limitation of periphyton in the River Thames: implications for catchment management. Sci Tot Environ 2012, this issue.

Burgin AJ, Yang WH, Hamilton SK, Silver WL. Beyond carbon and nitrogen: how the microbial energy economy couples elemental cycles in diverse ecosystems. Front Ecol Environ 2011;9:44-52.

Carpenter SR, Stanley EH, Van der Zanden MJ. State of the world's freshwater ecosystems: physical, chemical and biological changes. Ann Rev Environ Resources 2011; 36: 75-99.

Chapin FS III, Power ME, Cole JJ. Coupled biogeochemical cycles and earth stewardship. Front Ecol Environ 2011; 9: 3.

Chapin FS III, Carpenter SR, Kofinas GP, Folke C, Abel N, Clark WC, et al. Ecosystem stewardship: sustainability strategies for a rapidly changing planet. Trends Ecol Evolut 2010; 25: $241-49$.

Conley DJ, Paerl HW, Howarth RW, Boesch DF, Seitzinger SP, Havens KE, et al. Controlling eutrophication: nitrogen and phosphorus. Science 2009; 323: 1014-15. 
Cordell D, Drangert J-O, White S. The story of phosphorus: global food security and food for thought. Global Environ Change-Human Policy Dimensions 2009; 19: 292-305.

Copertino M da S. (2011) Add coastal vegetation to the climate critical list. Nature 2011;473: 255.

Costanza R, d'Arge R, deGroot R, Farber S, Grasso M, Hannon B, et al. The value of the world's ecosystem services and natural capital. Nature 1997; 387: 253-60.

Dawson JJC, Adhikari YR, Soulsby C, Stutter MI. The biogeochemical reactivity of suspended particulate matter at nested sites in the Dee basin, NE Scotland. Sci Tot Environ 2012, this issue.

Diaz RJ, Rosenberg R. Spreading dead zones and consequences for marine ecosystems. Science 2008;321:926-9.

Dungait JAJ, Cardenas LM, Blackwell MSA, Wu L, Withers PJA, Chadwick DR et al. Advances in the understanding of nutrient dynamics and management in UK agriculture. Sci Tot Environ 2012, this issue.

Edwards AC, Watson HA, Cook YEM. Source strengths, transport pathways and delivery mechanisms of nutrients, suspended solids and coliforms within a small agricultural headwater catchment. Sci Tot Environ 2012, this issue.

Edwards AC, Withers PJA. Transport and delivery of suspended solids, nitrogen and phosphorus from various sources to freshwaters in the UK. J Hydrol 2008; 350: 144-53.

Erisman JW, Sutton MA, Galloway J, Klimont Z and Winiwarter W. How a century of ammonia synthesis changed the world. Nature Geoscience 2008;1:636-9.

Elser JJ, Bennett E. A broken biogeochemical cycle. Nature 2011; 478: 29-31.

Elser JJ, Bracken MES, Cleland EE, Gruner DS, Harpole WS, Hillebrand H, et al. Global analysis of nitrogen and phosphorus limitation of primary producers in freshwater, marine and terrestrial ecosystems. Ecol Lett 2007; 10: 1135-42.

Evans C, Monteith D, Cooper D. Long-term increases in surface water dissolved organic carbon: observations, possible causes and environmental impacts. Environ Poll 2005; 137: $55-71$.

Filippelli GM. The global P cycle: past, present and future. Elements 2008;4:89-95.

Finzi AC, Austin AMYT, Cleland EE, Frey SD, Houlton BZ, Wallenstein MD. Responses and feedbacks of coupled biogeochemical cycles to climate change: examples from terrestrial ecosystems. Front Ecol Environ 2011a; 9: 61-7. 
Finzi AC, Cole JJ, Doney SC, Holland EA, Jackson RB. Research frontiers in the analysis of coupled biogeochemical cycles. Front Ecol Environ 2011b; 9: 74-80.

Foley JA, Ramankutty N, Brauman KA, Cassidy ES, Gerber JS, Johnston M, et al. Solutions for a cultivated planet. Nature 2011; 478: 337-42.

Fowler D, Smith R, Muller JBA, Cape JN, Sutton M, Erisman JW, et al. Long term trends in sulphur and nitrogen deposition in Europe and the cause of non-linearities. In: Brimblecombe P, Hara H, Houle D, Novak M, editors. Acid rain - deposition to recovery. Dordrecht, Netherlands: Springer; 2007. p. 41-7.

Godfray HCJ, Beddington JR, Crute IR, Haddad L, Lawrence D, Muir JF, Food security: the challenge of feeding 9 billion people. Science 2010; 327: 812-8.

Halliday SJ, Wade AJ, Skeffington RA, Neal C, Reynolds B, Rowland P, Neal M, Norris D. New inferences from long term trends, seasonality and shifts in phase and amplitude of upland hydrochemistry, Plynlimon, Wales. Sci Tot Environ 2012, this issue.

Harpole W, Ngai JT, Cleland EE, Seabloom EW, Borer ET, Bracken MES, et al. Nutrient colimitation of primary producer communities. Ecol Lett 2011;14:852-62.

Hill PW, Quilliam RS, DeLuca TH, Farrar J, Farrell M, et al. (2011). Acquisition and assimilation of nitrogen as peptide-bound and D-enantiomers of amino acids by wheat. PLoS ONE 6:e19220. doi:10.1371/journal.pone.0019220.

IPCC. Climate Change 2007: The Physical Science Basis. Contribution of Working Group I to the Fourth Assessment Report of the Intergovernmental Panel on Climate Change. Editors Solomon S, Qin D, Manning M, Chen Z, Marquis M, Averyt KB, Tignor M, Miller HL. Cambridge: Cambridge University Press: 2007.

Isaac ME, Hinsinger P, Harmand JM. Nitrogen and phosphorus economy of a legume treecereal intercropping system under controlled conditions, Sci Tot Environ 2012, this issue.

Jarvie HP, Neal C, Rowland AP, Neal M, Morris PN, Lead JR, et al. Role of riverine colloids in macronutrient and metal partitioning and transport, along an upland-lowland land-use continuum, under low-flow conditions. Sci Tot Environ 2012, this issue.

Jickells TD. Nutrient biogeochemistry of the coastal zone. Science 1998;281:217-22.

Jordan P, Melland AR, Mellander P-E, Shortle G, Wall D. The seasonality of phosphorus transfers from land to water: Implications for trophic impacts and policy evaluation, Sci Tot Environ 2012, this issue.

Kirchner JW, Feng X, Neal C. Fractal stream chemistry and its implications for contaminant transport in catchments. Nature 2000; 403: 524-7. 
Ma L, Velthof GL, Wang FH, Qin W, Zhang WF, Liu Z et al., Nitrogen and phosphorus use efficiencies and losses in the food chain in China at regional scales in 1980 and 2005. Sci Tot Environ 2012, this issue.

Mahowald N, Jickells TD, Baker AR, Artaxo P, Benitez-Nelson CR, Bergametti G. et al. Global distribution of atmospheric phosphorus sources, concentrations and deposition rates, and anthropogenic impacts. Global Biogeochem Cycles 2008; 22: GB4026.

Maier G, Glegg G, Tappin AD, Worsfold PJ. A high resolution temporal study of phytoplankton bloom dynamics in the eutrophic Taw Estuary (SW England). Sci Tot Environ 2011, this issue.

Manzoni S, Porporato A. Common hydrologic and biogeochemical controls along the soilstream continuum. Hydrol Process 2011; 25: 1355-1360.

Matear RJ, Wang YP, Lenton A. Land and ocean nutrient and carbon cycle interactions. Current Opinion Environ Sustainability 2010; 2: 258-263.

McLeod AR, Holland MR, Shaw PJA, Sutherland PM, Darrall NM, Skeffington RA. Enhancement of nitrogen deposition to forest trees exposed to SO2. Nature 1990; 347: 277-9.

Moss, B. Cogs in the endless machine: Lakes, climate change and nutrient cycles: a review. Sci Tot Environ 2012, this issue.

Neal C, Reynolds B, Rowland P, Norris D, Kirchner JW, Neal M, et al. High-frequency water quality time series in precipitation and streamflow: from fragmentary signals to scientific challenge. Sci Tot Environ, 2012 this issue.

Neal C, Neal M, Reynolds B, Maberly SC, May L, Ferrier RC, et al. Silicon concentrations in UK surface waters. J Hydrol 2005;304:75-93.

Newell-Price JP, Harris D, Taylor M, Williams JR, Anthony SG, Duethmann D, et al. (ADAS, UK). An inventory of mitigation methods and their effects on diffuse water pollution, greenhouse gas emissions and ammonia emissions from agriculture. Final Report. 2011. http://randd.defra.gov.uk/Document.aspx?Document=MitigationMethodsUserGuideDecember2011FINAL.pdf. [Accessed June 2012]. DEFRA Project WQ0106.

Palmer-Felgate EJ, Mortimer RJG, Krom MD, Jarvie HP, Williams RJ, Spraggs RE, et al. Internal loading of phosphorus in a sedimentation pond of a treatment wetland: Effect of a phytoplankton crash. Sci Tot Environ 2011; 409: 2222-32.

Paerl HW. Controlling eutrophication along the freshwater-marine continuum: Dual nutrient $(\mathrm{N}$ and $\mathrm{P})$ reductions are essential. Estuaries Coasts 2009;32:593-601.

Pilkington M, Caporn S, Carroll J, Cresswell N, Lee J, Emmett B, Johnson D. Effects of increased deposition of atmospheric nitrogen on an upland Calluna moor: $\mathrm{N}$ and $\mathrm{P}$ transformations. Environ Poll 2005; 135: 469-80. 
Prudhomme C, Young A, Watts G, Haxton T, Crooks S, Williamson J, Davies H, Dadson S, Allen S. The drying up of Britain? A national estimate of changes in seasonal river flows from 11 regional climate model simulations. Hydrol Proc 2012; 26: 1115-8.

Quinton JN, Govers G, Van Oost K, Bardgett RD. The impact of agricultural soil erosion on biogeochemical cycling. Nature Geoscience 2010; 3: 311-4.

Roose T, Schnepf A. Mathematical models of plant-soil interaction. Phil Trans Roy Soc Math Eng Sci 2008;366:4597-4611.

Rowe EC, Emmett BA, Frogbrook ZL, Robinson, DA, Hughes S. Nitrogen deposition and climate effects on soil nitrogen availability: Influences of habitat type and soil characteristics. Sci Tot Environ, 2012, this issue.

Royal Society. Reaping the benefits: science and the sustainable intensification of global agriculture. London: Royal Society; 2009.

Schade JD, MacNeill K, Thomas SA, McNeely FC, Welter JR, Hood J, et al. The stoichiometry of nitrogen and phosphorus spiralling in heterotrophic and autotrophic streams. Freshwater Biology 2011; 56: 424-436.

Schlesinger WH. Biogeochemistry: an analysis of global change. New York: Academic Press; 1997.

Schlesinger WH, Cole JJ, Finzi AC, Holland EA. Introduction to coupled biogeochemical cycles. Front Ecol Environ 2011; 9: 5-8.

Skeffington RA, Hill TJ. The effects of a changing pollution climate on throughfall deposition and cycling in a forested area in southern England, Sci Tot Environ, 2012, this issue.

Smith VH, Schindler DW. Eutrophication science: where do we go from here? Trends Ecol Evol 2009;24:201-7.

Statham PJ. Nutrients in estuaries - An overview and the potential impacts of climate change, Sci Tot Environ, 2012, this issue.

Stenberg M, Ulén B, Söderström M, Roland B, Delin K, Helander C-A. Tile drain losses of nitrogen and phosphorus from fields under integrated and organic crop rotations. A four-year study on a clay soil in southwest Sweden, Sci Tot Environ, 2012, this issue.

Sterner RW, Elser JJ. Ecological stoichiometry: The biology of elements from molecules to the biosphere. Princeton, USA: Princeton University Press; 2002.

Tetzlaff D, Capell R, Soulsby C. Land use and hydroclimatic influences on faecal indicator organisms in two large Scottish catchments: Towards land use-based models as screening tools. Sci Tot Environ, 2012, this issue. 
Trimmer M, Grey J, Heppell CM, Hildrew A, Yvon-Rocher G. River bed carbon and nitrogen cycling: state of play and some new directions. Sci Tot Environ 2012, this issue.

Vitousek PM, Naylor R, Crews T, David MB, Drinkwater LE, Holland E, et al. Nutrient imbalances: pollution remains response. Science 2009; 326: 665-666.

Vitousek PM, Porder S, Houlton BZ, Chadwick OA. Terrestrial phosphorus limitation: mechanisms, implications, and nitrogen-phosphorus interactions. Ecol Applications 2010; 20: $5-15$.

von Bodungen V, Turner K (eds.) Science and Integrated Coastal Management. Berlin: Dahlem University Press;1999.

Wade AJ, Palmer-Felgate EJ, Halliday SJ, Skeffington RA, Loewenthal M, Jarvie HP et al. From existing in situ, high-resolution measurement technologies to lab-on-a-chip - the future of water quality monitoring? Hydrol Earth System Sci Discussion 2012; 9: 6457-6506.

Watson A, Nedwell D. Methane production and emission from peat: the influence of anions (sulphate, nitrate) from acid rain . Atmos Environ 1998; 32: 3239-45.

Whitehead PG, Crossman J. Macronutrient cycles and climate change: key science areas and international perspective. Sci Tot Environ 2012, this issue.

Withers PJA, Jarvie HP. Delivery and cycling of phosphorus in rivers: a review. Sci Tot Environ 2008; 400: 379-395.

Worrall F, Davies H, Burt T, Howden NJK, Whelan MJ, Bhogal A et al.The flux of dissolved nitrogen from the UK - Evaluating the role of soils and land use. Sci Tot Environ 2012, this issue. 